\title{
Behavioral Intention of Domestic Chinese Tourists Staying at Lijiang Ancient City Bed and Breakfast Establishments
}

\author{
Gang Chen, Fuangfa Amponstira \\ School of Management, Shinawatra University, Bangkok, Thailand \\ Email: gangchen1226@126.com, fuangfa.a@siu.ac.th
}

How to cite this paper: Chen, G., \& Amponstira, F. (2020). Behavioral Intention of Domestic Chinese Tourists Staying at Lijiang Ancient City Bed and Breakfast Establishments. Modern Economy, 11, 793-806. https://doi.org/10.4236/me.2020.114059

Received: February 23, 2020

Accepted: April 13, 2020

Published: April 16, 2020

Copyright $\odot 2020$ by author(s) and Scientific Research Publishing Inc. This work is licensed under the Creative Commons Attribution International License (CC BY 4.0).

http://creativecommons.org/licenses/by/4.0/

\section{(c) (i) Open Access}

\begin{abstract}
Lijiang ancient city is an example of an emergent heritage tourism site aimed at both domestic and international tourism in China. The domestic tourism industry is generally flourishing, although it has been overshadowed to some extent by the international sector. In order to maintain heritage sites, large scale redevelopments to build large hotels are being avoided and, instead, local facilities are being promoted in the form of bed and breakfast (B\&B) establishments. It is not clear whether tourist behavioral intention in this emergent sector will be the same as found elsewhere and so a program of quantitative research was established to examine the ways in which tourists behave and form and enact their intentions. A total of 400 questionnaires was completed and subsequently analysed through various statistical techniques. Research hypotheses linking conventional forms of behaviour to tourist behaviour in this respect were accepted and it was concluded that similar marketing techniques that have been proved to be successful elsewhere would also be successful in the case of this sector.
\end{abstract}

\section{Keywords}

Lijiang Ancient City, Bed and Breakfast (B\&B), Behavioral Intention, Heritage Tourism

\section{Introduction}

While the development of Chinese tourism has become most noticeable in its international context, it has also become a notable phenomenon in the domestic context. In 2019, Chinese made 155 million outbound trips and 6.06 billion domestic trips, an increase of $8.4 \%$ over 2018 (China Industry Information Network, 2020). These increases result from not just increased incomes and stan- 
dards of living but, also, from improved infrastructure (e.g. domestic airports, high speed rail links and freeways), as well as wider aspirations owing in part to better knowledge of potential destinations through online information. During the 2019 National Day holiday period, for example, some 732 million domestic trips were held, with $79.8 \%$ of tourists participating in Red Tourism activities (i.e. commemorating the founding of the People's Republic of China), $66.4 \%$ visiting culture and history-themed sites and $45.0 \%$ participating in night-time activities (China Daily, 2019). Most trips are being made to the large and most developed Chinese cities of Shanghai, Beijing, Guangzhou and Shenzhen, followed by more picturesque destinations in Hainan Island and Yunnan and Sichuan provinces and the mountains of north-east China (Sampson, 2018).

Although some parts of this industry feature contemporary hotels and urban environment, some aspects of heritage tourism have also become important. The "heritage" element relates to the natural, cultural and built environments of an area and, hence, has an inescapable relationship with the need for conservation of the designated heritage area (Millar, 1989). Further, the heritage element of tourism is such that "the perception of a place as part of personal heritage is associated with the visitation patterns". In particular, those who view a place as bound up with their own heritage are likely to behave significantly different from others (Poria, Butler, \& Airey, 2003). Destination management, in the contest of heritage tourism, therefore involves the attempt to enhance feelings among tourists and potential tourists of being part of the shared heritage, by such means as enhancing the quality of communication to consumers and the fostering of feelings of joint membership of heritage legacies. In studying contemporary China, it has become a commonly-held but contested view that nationalism is rising among the population of China, especially its younger members, for a variety of reasons including state support (Johnston, 2017). Successful destination management will, in various ways, link these two forces together, with or without the political element embedded in nationalism.

The practical implications of this include the need to enhance the carrying capacity of an area in terms of tourism management without the extensive real development required to meet contemporary expectations of accommodation and entertainment. One means of dealing with this issue has been the renewed emphasis placed upon traditional forms of accommodation such as bed and breakfast $(B \& B)$. A B\&B is defined here as the situation in which a building owner uses idle houses or rooms within the building, together with local human and natural landscape resources to provide for tourists' accommodation, including breakfast, as well as some experience of the texture of local life (Ding \& $\mathrm{Li}, 2017)$. B\&Bs provide opportunities for increasing the feelings of belonging to the heritage tourism sites offered to people without disrupting any further the development and physical infrastructure of a location. Government support has meant that the number of $\mathrm{B} \& \mathrm{Bs}$ in ancient cities throughout the country has risen by 78\% in two years from 9431 in 2016 to 16,787 by the end of 2018 (China 
National Tourism Administration, 2018). The sector has become increasingly competitive, that is, and the focus has begun to switch from production-orientation to customer-orientation.

The sector is governed by the relevant provisions of Article 22 of the Regulations on the Protection and Planning of Ancient Cities promulgated by the China State Administration of Cultural Relics (1985), which inhibits the ability of private and public sector agencies to build new hotels in areas designated as being ancient cities. Lijiang, in Yunnan province, has obtained "ancient city" status on the basis of its 800-year history and its longstanding relationship with the unique Naxi Dongba ethnic minority people. It includes Dayan old town, Baisha old town and Shuhe old town (Yunnan Cultural Toursim Bureau, 2006). Much of the old town district had to be rebuilt after a 7.0 magnitude earthquake which struck in 1996 and fire remains a persistent threat in the densely-crowded urban environment.

Although there is quite a significant strand of literature dealing linking the behavioural intentions of consumers with various aspects of customer satisfaction such as functional value, service value, social value and so forth. Consequently, robust methodologies have been developed for quantitative research in this area. However, research among Chinese consumers is still at an early stage because of the fact that the domestic tourism sector has only become of interest in the last few years. To date, research among domestic tourists has not often passed the level of who is doing what and why and has not dealt in depth with the B\&B sector outlined here. For example, Wang (2010) has calculated the numbers and flows of Chinese domestic tourists and argued that these result from the presence of existing infrastructure rather than from government policy. Wen (1997) and $\mathrm{Wu}$, Zhu and Xu (2000) highlighted the past history of domestic tourism in China and sought to explain how and why it would change in the future. Yang, Liu and Qi (2014), meanwhile, take advantage of some parts of the new stream of national state-provided statistics about tourism to start to try to segment different sections of the overall tourism market. There are more works available in Chinese language but the central point remains valid that important aspects of consumer behaviour in domestic tourism in ancient city B\&B in China remain under-researched. This prompts the following research questions:

1) What is the relationship between customer perceived value and behavioral intention among Chinese domestic tourists in Lijiang ancient city B\&B?

2) What is the relationship between customer perceived value and customer satisfaction among Chinese domestic tourists in Lijiang ancient city $\mathrm{B} \& \mathrm{~B}$ ?

The paper continues with a description of the methodology by which it was attempted to answer these research questions, followed by the statistical analysis and hypothesis testing, discussion of the findings and the concomitant claim to contribution to academic knowledge and then the conclusion and list of references. 


\section{Materials and Methods}

This project focused on a quantitative approach since the literature review revealed that a considerable amount of work had been done in terms of understanding the issues of customer's future behavioral intention in other contexts. Further, validated quantitative instruments have been used to explore these areas and, with suitable precautions, it was deemed appropriate to extend them to the new area of domestic heritage city tourism in China. Based on the literature review and the research questions, the following hypotheses were created:

H1: There is a significant relationship between customer perceived value (CPV) with customer satisfaction (CUS).

H1a: There is a significant relationship between functional value (FUV) with customer satisfaction (CUS).

H1b: There is a significant relationship between service value (SEV) with customer satisfaction (CUS).

H1c: There is a significant relationship between social value (SOV) with customer satisfaction (CUS).

H1d: There is a significant relationship between emotional value (EMV) with customer satisfaction (CUS).

H1e: There is a significant relationship between cultural cognitive value (CCV) with customer satisfaction (CUS).

H2: There is a significant relationship between customer perceived value (CPV) with behavioral intention (BEI).

H2a: There is a significant relationship between functional value (FUV) with behavioral intention (BEI).

H2b: There is a significant relationship between service value (SEV) with behavioral intention (BEI).

$\mathrm{H} 2 \mathrm{c}$ : There is a significant relationship between social value (SOV) with behavioral intention (BEI).

H2d: There is a significant relationship between emotional value (EMV) with behavioral intention (BEI).

H2e: There is a significant relationship between cultural cognitive value (CCV) with behavioral intention (BEI).

These hypotheses were converted to null format for formal testing. They may be represented by the conceptual framework (see Figure 1, below).

The individual variables within these subsets have been tested and validated in a variety of peer-reviewed academic papers. Specifically, variants of the current posited model have been employed in a range of different tourism contexts (see Table 1 below).

At present, there are few studies on the dimensions of customer perceived value in the field of tourism. But the four dimensions of social value, emotional value, service value and functional value appear frequently and have certain universality. Secondly, the author also finds that if the object of study has certain historical and cultural connotations, then the dimension of perceived value often contains cultural cognitive value. 
Customer Perceived Value

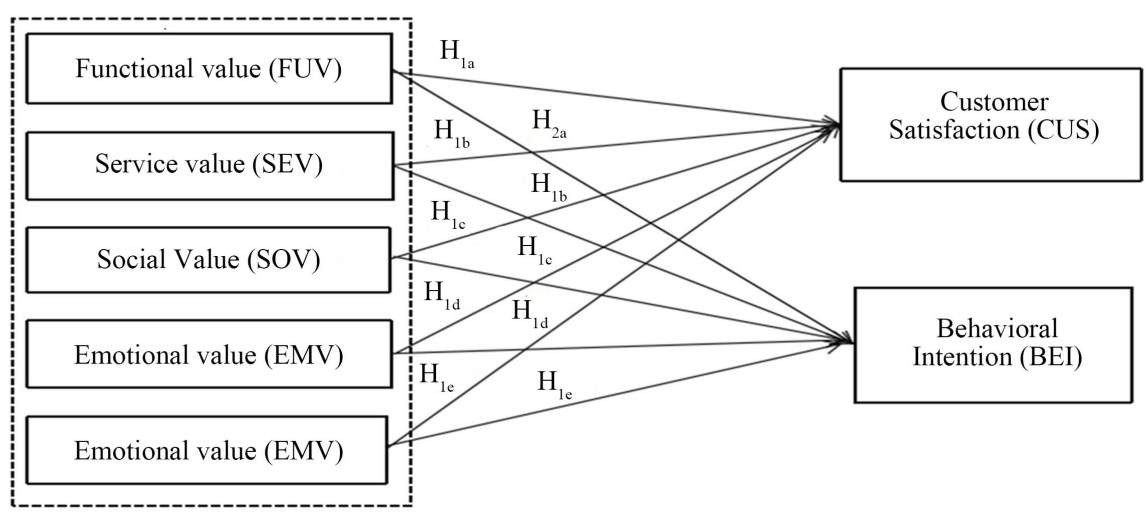

Figure 1. Conceptual framework; Source: Authors.

Table 1. Dimensions of customer perceived value in tourism.

\begin{tabular}{|c|c|c|c|}
\hline Author(s) & Tourism Situation & Case & Dimension(s) \\
\hline Wang (2018) & Rural Tourist & $\begin{array}{l}\text { Tourist Center of Linan } \\
\text { Grand Canyon Village, } \\
\text { Zhejiang Province }\end{array}$ & $\begin{array}{l}\text { Service Quality, Service Facilities, } \\
\text { Architecture and Environment, } \\
\text { Functional Value }\end{array}$ \\
\hline $\begin{array}{l}\text { Scaglione \& } \\
\text { Mendola } \\
(2017)\end{array}$ & Destination & $\begin{array}{l}\text { Sicily Agricultural Tourist } \\
\text { Area }\end{array}$ & $\begin{array}{l}\text { Functional Value, Convenience } \\
\text { Value, Emotional Value, Social } \\
\text { Value and Educational Value }\end{array}$ \\
\hline $\begin{array}{l}\text { Lee et al. } \\
(2007)\end{array}$ & $\begin{array}{l}\text { War-related } \\
\text { Tourism }\end{array}$ & $\begin{array}{l}\text { South Korea Militarized } \\
\text { Area }\end{array}$ & $\begin{array}{l}\text { Functional Value, Emotional } \\
\text { Value, Whole Value }\end{array}$ \\
\hline $\operatorname{Li}(2011)$ & $\begin{array}{l}\text { Recreation around } \\
\text { Metropolis }\end{array}$ & $\begin{array}{l}\text { Beihai Park, East Lake } \\
\text { Scenic Area, }\end{array}$ & $\begin{array}{l}\text { Functional Value, Emotional } \\
\text { Value, Cultural Cognitive Value, } \\
\text { Economic Value, Situational } \\
\text { Value }\end{array}$ \\
\hline $\begin{array}{l}\text { Wang et al. } \\
\text { (2011) }\end{array}$ & & Shanghai World Expo & $\begin{array}{l}\text { Service Value, Convenience } \\
\text { Value, Aesthetic Value, Perceived } \\
\text { Price, Functional Utility Value, } \\
\text { Pleasure Value }\end{array}$ \\
\hline $\begin{array}{l}\text { Ma \& Bao } \\
(2012)\end{array}$ & & $\begin{array}{l}\text { Xishuangbanna, Yunnan } \\
\text { Province }\end{array}$ & $\begin{array}{l}\text { Cultural Value, Hedonic Value, } \\
\text { Social Value, Service Value, } \\
\text { Convenience Value, Situational } \\
\text { Value, Functional Value }\end{array}$ \\
\hline $\begin{array}{l}\text { Zhang \& Jia } \\
\text { (2008) }\end{array}$ & $\begin{array}{l}\text { Festivals/Festivals/ } \\
\text { Cultural Tourism }\end{array}$ & Festival Tourism & $\begin{array}{l}\text { Convenience Value, Service } \\
\text { Value, Aesthetic Value, Social } \\
\text { Value, Entertainment Value }\end{array}$ \\
\hline $\begin{array}{l}\text { Yang } \\
(2013)\end{array}$ & & $\begin{array}{l}\text { Japanese Traditional } \\
\text { Festivals }\end{array}$ & $\begin{array}{l}\text { Functional Value, Economic } \\
\text { Convenience Value, Cultural } \\
\text { Cognitive Value, Situational } \\
\text { Value, Social Value, Emotional } \\
\text { Hedonic Value }\end{array}$ \\
\hline Pan (2008) & & $\begin{array}{l}\text { Cultural Tourism in } \\
\text { Qingzhou, Korea }\end{array}$ & $\begin{array}{l}\text { Functional Value, Emotional } \\
\text { Value, Social Value, Knowledge } \\
\text { Value, Situational Value }\end{array}$ \\
\hline Liu (2011) & $\begin{array}{l}\text { Historical and } \\
\text { Cultural Heritage } \\
\text { Sites }\end{array}$ & $\begin{array}{l}\text { Wuhou Temple of } \\
\text { Chengdu }\end{array}$ & $\begin{array}{l}\text { Quality Value, Cost Value, } \\
\text { Efficiency Value, Service Value, } \\
\text { Social Value, Emotional Value, } \\
\text { Aesthetic Value, Place Value, } \\
\text { Cognitive Value }\end{array}$ \\
\hline
\end{tabular}




\section{Continued}

\begin{tabular}{|c|c|c|c|}
\hline Li \& Zhang (2010) & & Zhang Guying Village & $\begin{array}{l}\text { Social Value, Emotional Value, } \\
\text { Cognitive Value, Functional } \\
\text { Value }\end{array}$ \\
\hline $\begin{array}{l}\text { Rasoolimanesh et } \\
\text { al. (2016) }\end{array}$ & & Lenggong Valley, Malaysia & $\begin{array}{l}\text { Functional Value, Emotional } \\
\text { Value, Social Value }\end{array}$ \\
\hline $\begin{array}{l}\mathrm{Li} \\
(2018)\end{array}$ & & $\begin{array}{l}\text { Hangzhou Longjing Tea } \\
\text { Garden }\end{array}$ & $\begin{array}{l}\text { Cognitive Value, Social Value, } \\
\text { Functional Value }\end{array}$ \\
\hline $\begin{array}{l}\text { Zhao et al. } \\
\text { (2018) }\end{array}$ & $\begin{array}{l}\text { Parks } \\
\text { \&Ecotourism } \\
\text { Scenic Spots }\end{array}$ & $\begin{array}{l}\text { Xixi National Wetland } \\
\text { Park }\end{array}$ & $\begin{array}{l}\text { Service Value, Cognitive Value, } \\
\text { Emotional Value, Characteristic } \\
\text { Value, Environmental Value, Cost } \\
\text { Value, Management Value, Trust } \\
\text { Value }\end{array}$ \\
\hline $\begin{array}{l}\text { Cheng } \\
(2006)\end{array}$ & & $\begin{array}{l}\text { Forest Ecotourism Scenic } \\
\text { Area }\end{array}$ & $\begin{array}{l}\text { Service Value, Functional Value, } \\
\text { Characteristic Value, Brand } \\
\text { Value, Educational Value, } \\
\text { Emotional Value, Perceived Cost, } \\
\text { Environmental Value }\end{array}$ \\
\hline $\begin{array}{l}\text { Lu et al. } \\
(2018)\end{array}$ & Ski Resort & $\begin{array}{l}\text { Yunding Ski Resort in } \\
\text { Chongli }\end{array}$ & $\begin{array}{l}\text { Facility Quality Perception, } \\
\text { Service Quality Perception, } \\
\text { Emotional Value, Monetary Cost } \\
\text { Perception, Non-monetary Cost } \\
\text { Perception }\end{array}$ \\
\hline $\begin{array}{l}\text { Liu et al. } \\
\text { (2019) }\end{array}$ & & Luxury Hotel & $\begin{array}{l}\text { Emotional Value, Hedonic Value, } \\
\text { Symbolic Value, Functional Value }\end{array}$ \\
\hline $\begin{array}{l}\mathrm{Xu} \\
(2015)\end{array}$ & & Economy Hotel & $\begin{array}{l}\text { Quality, Economic Cost, } \\
\text { Non-Economic Cost, Social Value } \\
\text { and Emotional Value }\end{array}$ \\
\hline $\begin{array}{l}\text { Zheng } \\
(2014)\end{array}$ & & Ecotype Boutique Hotel & $\begin{array}{l}\text { Flaunting Value, Unique Value, } \\
\text { Functional Value and Self-Value }\end{array}$ \\
\hline $\begin{array}{l}\text { Fu \& Liu } \\
(2014)\end{array}$ & $\begin{array}{l}\text { Accommodation } \\
\text { Industry }\end{array}$ & $\begin{array}{l}\text { Yangshuo Flower } \\
\text { International Youth } \\
\text { Hostel }\end{array}$ & $\begin{array}{l}\text { Functional Value, Service Value, } \\
\text { Emotional Value, Social Value, } \\
\text { Eco-environmental Value }\end{array}$ \\
\hline Liang \& Jia (2018) & & $\begin{array}{l}\text { "Ten Thousand Hostel" in } \\
\text { Zengcheng of Guangzhou }\end{array}$ & $\begin{array}{l}\text { Emotional Value, Service Value, } \\
\text { Convenience Value, Reference } \\
\text { Value, Cost Value }\end{array}$ \\
\hline $\begin{array}{l}\text { Wang } \\
(2019)\end{array}$ & & $\begin{array}{l}\text { B\&B in Banan District of } \\
\text { Chongqing }\end{array}$ & $\begin{array}{l}\text { Emotional Value, Service Value, } \\
\text { Convenience Value, } \\
\text { Environmental Value, Reference } \\
\text { Value and Functional Value }\end{array}$ \\
\hline
\end{tabular}

Source: Authors, adopted from various sources.

The assembled questionnaire was then given to a noted academic in the field of tourism management and whose first language was Chinese to determine congruity in meaning between Chinese and English. Once this stage was passed satisfactorily, the questionnaire was distributed to five other academics in relevant fields of expertise for their consideration and comment. Finally, a pilot test of 30 questionnaires was conducted to determine whether there were any remaining issues of question wording or ordering or any other issues outstanding. The quality assurance issues were passed and a Cronbach's alpha score of 0.971 was achieved, which was comfortably more than the 0.7 level required for statistical analysis to go ahead. 


\subsection{Sample}

In this study, questionnaires were used as the main tool to collect the original data of sample groups. The target population of this study includes tourists who have stayed at Lijiang ancient city B\&B at least one day. This study was conducted from October to December 2019 in the form of self-service questionnaires, which were distributed to Chinese tourists during the check-in process by receptionists of the Lijiang ancient city $\mathrm{B} \& \mathrm{Bs}$. According to the data released by Lijiang Tourism Bureau in 2020, there are 120 registered ancient city B\&Bs in Lijiang ancient city, with total about 534,000 tourists stayed there (Lijiang Tourism Bureau, 2020).

The sample size of the respondents for this study was calculated using Taro Yamane's formula (Yamane, 1973) with 95\% confidence level, the sample size can be roughly estimated as follows:

$$
n=\frac{N}{1+N e^{2}}
$$

where,

$$
\begin{aligned}
& n=\text { Sample size } \\
& N=\text { Population size }(534,000) \\
& e=\text { Sampling error assumed as } 0.5 \\
& \text { Determining sample size by following application; }
\end{aligned}
$$

$$
\text { Sample size }=534,000 /\left[1+534,000 \times(0.05)^{2}\right]=399.7
$$

According to the Yamane equation, with a large sample size such as the annual number of tourists to Lijiang and a $95 \%$ level of confidence, a sample size of 400 is required. This sample size was achieved by distributing a sufficient number of the self-completion questionnaires at various B\&Bs in Lijiang ancient city and then collecting the completed forms by hand subsequently.

\subsection{Sampling}

Convenient sampling was adopted due to the unidentified population and sampling frame as well as the nature of the study itself. Moreover, this study used non-random sampling because no list existed of the population of all tourists who have stayed at Lijiang ancient city B\&Bs that could be used for random selection. Therefore, a non-random sample was the only alternative. Convenient sampling is characterized by the use of the sample that is convenient to the researcher and that includes only individuals who agreed to participate (Jamal, Othman, \& Muhammad, 2011).

This approach is a convenience sampling approach and has the limitation that it is not possible to control the demographic characteristics of respondents and so there is a possibility of non-response bias for some demographic categories and this is a research limitation. However, random sampling was not practical and there was no master list of potential respondents which could have been used in such a case. Instead, just over $10 \%$ of the total of 120 B\&Bs in Lijiang an- 
cient city were selected and received stocks of questionnaires for distribution. $B \& B s$ were selected with a view to obtaining heterogeneity in the sample through different locations, costs and so forth. B\&B managers were incentivised for this purpose.

Once the completed questionnaires were collected, they were checked for completeness and accuracy and then entered into the SPSS program for analysis. The data set thus created was checked and then analysed through descriptive statistics and then factor analysis and correlation analysis was conducted so as to test the research hypotheses.

\section{Findings}

Lijiang's B\&B sector reflects the unique characteristics of the tourism sector in the city as a whole, since it combines elements not just of traditional Chinese elements with those of the Naxi Dongba culture and, also, the ancient tea-horse trade route which brings in Tibetan influence to the city. B\&Bs are unevenly distributed through the city, with $86.6 \%$ of the total located in Dayan old town, notably near Sifang Street, Lion Hill, Wuyi Street, Xinyi Street, Guangyi Street and other densely-populated areas. The remaining $13.4 \%$ of B\&Bs are located in Shuhe old town, primarily along Liren road and Zhonghe Road. B\&Bs may be divided into traditional courtyard style of house which indicates it is the original configuration with three squares and one wall, with a small internal courtyard where additional activities may be located, and the boutique business style, which are more contemporary buildings in style which, nevertheless, incorporate some Lijiang elements to help convince tourists that they are taking part in heritage tourism activities. Of all B\&Bs in Lijiang ancient city, $41 \%$ are of the self-operated mode, in which building owners themselves offer B\&B services and frequently tend to emphasise local cultural factors, while the remaining 59\% take the rental mode, in which an operator rents the building from its owner and manages the B\&B business within it (Lijiang Tourism Bureau, 2019). This mode is thought to be capital-driven in nature and it is less likely, consequently, to incorporate what might be perceived to be authentic cultural and tourism institutes in its offering.

Of the sample achieved $(\mathrm{n}=400), 176(44.0 \%)$ were male and $224(56.0 \%)$ were female, which perhaps reflects the fact that women are more likely to respond to requests for feedback than men. The age profile of the sample was quite young, with $144(36.0 \%)$ aged 26 - 35 years, $128(32.0 \%)$ aged $19-25$ years and only $112(28.0 \%) 36$ years or older. The sample is also comparatively well-educated, with $112(28.0 \%)$ having a post-graduate degree and $248(62.0 \%)$ having a vocational or undergraduate degree.

On the whole, it appears that the sample is younger and better educated than the population overall and appears to have a good level of disposable income. It is reasonable to assume, therefore, that they will be quite adventurous in their leisure activities. This is evident from the booking behaviour of respondents, 
with $92.0 \%$ of respondents booking the accommodation themselves and only a small proportion requiring the help of a travel agent. B\&B managers must, therefore, be visible online. Repeat business is also a viable proposition, since $48.0 \%$ of respondents had visited Lijiang ancient city before and only $52.0 \%$ were experiencing their first visit. In terms of length of visit, $19.0 \%$ were visiting for up to 3 days, $55.0 \%$ for $4-7$ days and $26.0 \%$ for longer than a week. For cost, the most common categories of room rate per day were $201-400 \mathrm{CNY}(40.0 \%)$ and $401-600 \mathrm{CNY}$ (28.0\%) (1\$US = 7.0 CNY approximately). There are similar populations of respondents spending either less or more than this amount per day, although there does seem to be a niche market sector for high paying guests $(2000+$ CNT per day).

\section{Hypothesis Testing}

Regression and correlation analysis techniques were used to try to measure relationships if any between the various independent and dependent factors which were represented by the battery of variables that respondents were invited to consider. The Kaiser-Meyer-Olkin measure of sampling adequacy and the Bartlett's test of sphericity were both passed and so all variables were included in the subsequent analysis (see Table 2 below).

The results from Table 2 revealed that "prices are reasonable" $(X=4.01$, S.D. $=0.915)$ is the most satisfactory aspect of the ancient city B\&B for the respondents. Next followed by "the stay has helped me expand my horizons" $(X=3.93$, S.D. $=0.853)$ and "personalized services and advice are good" $(X=3.92$, S.D. $=$ $0.828)$. Surprisingly, the lowest score is "even if the price rises, I would still stay at this B\&B again" $(X=3.39$, S.D. $=0.935)$.

Correlation analysis indicated that there were significant relationships between the tested variables and both customer satisfaction and behavioral intention (see Table 3 below).

In this study, Pearson correlation coefficient was used to analyze the correlation among customer perceived value of ancient city $B \& B$ and its five dimensions, customer satisfaction and behavioral intention. The results of Table 3 show that the correlation coefficients among customer satisfaction and functional value, service value, social value, emotional value, cultural cognitive value and customer perceived value were respectively $0.513,0.484,0.463,0.516,0.492$, 0.633 , and they were significant positive correlation at the level of 0.01 . In addition, the correlation coefficients among behavioral intention and functional value, service value, social value, emotional value, cultural cognitive value and customer perceived value were respectively $0.594,0.635,0.557,0.607,0.636,0.771$, and they were significant positive correlation at the level of 0.01 . The research hypotheses with the following results (see Table 4 below).

The majority of the research hypotheses have been accepted and in the direction anticipated. This further indicates that the research concept is logical and coherent. 
Table 2. Descriptive statistics of variables tested in hypothesis testing.

\begin{tabular}{|c|c|c|c|}
\hline Category & Variable & Mean & S.D. \\
\hline FUV & Physical facilities are complete & 3.84 & 0.935 \\
\hline FUV & Prices are reasonable & 4.01 & 0.915 \\
\hline FUV & Good hygienic conditions & 3.86 & 0.950 \\
\hline FUV & Security for accommodation and activities is guaranteed & 3.76 & 0.953 \\
\hline SEV & Service staff are well-dressed and mannered & 3.88 & 0.814 \\
\hline SEV & Service staff have good attitudes & 3.75 & 0.788 \\
\hline SEV & Service staff work efficiently & 3.83 & 0.874 \\
\hline SEV & Personalized services and advice are good & 3.92 & 0.828 \\
\hline SOV & It is convenient to make new friends & 3.76 & 0.871 \\
\hline SOV & Harmonious interactions with other guests & 3.78 & 0.908 \\
\hline SOV & This experience will be interesting to others & 3.74 & 0.923 \\
\hline SOV & The environment enhances relationships with other people & 3.72 & 0.863 \\
\hline EMV & The stay makes me feel relaxed & 3.72 & 0.935 \\
\hline EMV & The stay makes me feel happy & 3.84 & 0.935 \\
\hline EMV & The stay is interesting and novel & 3.84 & 0.936 \\
\hline EMV & The stay is like being at home & 3.78 & 0.930 \\
\hline $\mathrm{CCV}$ & The stay has helped me expand my horizons & 3.93 & 0.851 \\
\hline $\mathrm{CCV}$ & The stay has helped me to experience a different lifestyle & 3.90 & 0.851 \\
\hline $\mathrm{CCV}$ & I have learned a lot about culture and customs & 3.82 & 0.895 \\
\hline $\mathrm{CCV}$ & The stay has helped me fit into the local culture & 3.71 & 0.851 \\
\hline CUS & Compared with expectations, you are satisfied & 3.57 & 0.773 \\
\hline CUS & You are satisfied on the whole & 3.85 & 0.773 \\
\hline CUS & $\begin{array}{c}\text { Compared with other accommodation of the same price, } \\
\text { you are satisfied with ancient city B\&B }\end{array}$ & 3.68 & 0.842 \\
\hline BEI & I would like actively to publicise this $B \& B$ to others & 3.72 & 0.833 \\
\hline BEI & I would like actively to recommend this $B \& B$ to others & 3.82 & 0.850 \\
\hline BEI & If I come here again, I will stay at this $\mathrm{B} \& \mathrm{~B}$ once more & 3.74 & 0.918 \\
\hline BEI & Even if the price rises, I would still stay at this $B \& B$ again & 3.39 & 0.935 \\
\hline
\end{tabular}

Source: original research.

Table 3. Correlation analysis.

\begin{tabular}{ccccccc}
\hline & FUV & SEV & SOV & EMV & CCV & CPV \\
\hline \multirow{2}{*}{ CUS } & $\begin{array}{c}0.513 \\
\left(0.000^{* *}\right)\end{array}$ & $\begin{array}{c}0.484 \\
\left(0.000^{* *}\right)\end{array}$ & $\begin{array}{c}0.463 \\
\left(0.000^{* *}\right)\end{array}$ & $\begin{array}{c}0.516 \\
\left(0.000^{* *}\right)\end{array}$ & $\begin{array}{c}0.492 \\
\left(0.000^{* *}\right)\end{array}$ & $\begin{array}{c}0.633 \\
\left(0.000^{* *}\right)\end{array}$ \\
BEI & $\begin{array}{c}0.594 \\
\left(0.000^{* * *}\right)\end{array}$ & $\begin{array}{c}0.635 \\
\left(0.000^{* *}\right)\end{array}$ & $\begin{array}{c}0.557 \\
\left(0.000^{* *}\right)\end{array}$ & $\begin{array}{c}0.607 \\
\left(0.000^{* *}\right)\end{array}$ & $\begin{array}{c}0.636 \\
\left(0.000^{* *}\right)\end{array}$ & $\begin{array}{c}0.771 \\
\left(0.000^{* *}\right)\end{array}$ \\
\hline
\end{tabular}

**. Correlation is significant at the 0.01 level (2-tailed). 
Table 4. Research hypothesis test results.

\begin{tabular}{|c|c|}
\hline Hypothesis & Results \\
\hline $\begin{array}{l}\text { H1: There is a significant relationship between customer perceived value (CPV) } \\
\text { with customer satisfaction (CUS). }\end{array}$ & Accepted \\
\hline $\begin{array}{l}\text { H1a: There is a significant relationship between functional value (FUV) with } \\
\text { customer satisfaction (CUS). }\end{array}$ & Accepted \\
\hline $\begin{array}{l}\text { H1b: There is a significant relationship between service value (SEV) with customer } \\
\text { satisfaction (CUS). }\end{array}$ & Accepted \\
\hline $\begin{array}{l}\text { H1c: There is a significant relationship between social value (SOV) with customer } \\
\text { satisfaction (CUS). }\end{array}$ & Accepted \\
\hline $\begin{array}{l}\text { H1d: There is a significant relationship between emotional value (EMV) with } \\
\text { customer satisfaction (CUS). }\end{array}$ & Accepted \\
\hline $\begin{array}{l}\text { H1e: There is a significant relationship between cultural cognitive value (CCV) } \\
\text { with customer satisfaction (CUS). }\end{array}$ & Accepted \\
\hline $\begin{array}{l}\mathrm{H} 2 \text { : There is a significant relationship between customer perceived value (CPV) } \\
\text { with behavioral intention (BEI). }\end{array}$ & Accepted \\
\hline $\begin{array}{l}\text { H2a: There is a significant relationship between functional value (FUV) with } \\
\text { behavioral intention (BEI). }\end{array}$ & Accepted \\
\hline $\begin{array}{l}\text { H2b: There is a significant relationship between service value (SEV) with } \\
\text { behavioral intention }(\mathrm{BEI}) \text {. }\end{array}$ & Accepted \\
\hline $\begin{array}{l}\mathrm{H} 2 \mathrm{c} \text { : There is a significant relationship between social value (SOV) with } \\
\text { behavioral intention (BEI). }\end{array}$ & Accepted \\
\hline $\begin{array}{l}\text { H2d: There is a significant relationship between emotional value (EMV) with } \\
\text { behavioral intention (BEI) }\end{array}$ & Accepted \\
\hline $\begin{array}{l}\text { H2e: There is a significant relationship between cultural cognitive value (CCV) } \\
\text { with behavioral intention (BEI). }\end{array}$ & Accepted \\
\hline
\end{tabular}

\section{Discussion}

The understanding of customer behavioral intention that has been developed through research of tourism activities mostly in the developed world also holds true for the Lijiang ancient city $\mathrm{B} \& \mathrm{~B}$ sector too. As might be expected, the basic motivations and methods of perceiving the world are the same for Chinese tourists as they are from tourists from other sites where research has been conducted. This further indicates that marketing techniques that are successful elsewhere should also work for Lijiang ancient city, albeit that there is a need to adjust the online media mix employed to meet the different usage patterns of Chinese consumers. The ways in which service providers can improve the services they offer are also those which will have been shown to be successful elsewhere.

Under the system of capitalist relations, customer's behaviour tends to become standardised as competing claims for utility maximisation under conditions of scarce resources and asymmetrical information tend to produce similar solutions. Since tourism of this type considered in this paper tends to be sociable in nature, then it is not surprising that this situation has occurred. It is possible that research among individual travellers, if this could have been managed, might have yielded different results. 
In terms of the basic concept of the ancient city $B \& B$, it appears that there is scope for employing these rather than redeveloping historical areas to build hotels. It is possible that this will lead to the requirement for demand management rather just permitting the continuous expansion of the hotel sector. This will have implications not just for urban management but also for the sustainability issues surrounding China and further afield.

\section{Conclusion}

This paper has reported on an investigation into 400 respondents to a quantitative survey aimed at discovering behavioral intention of Chinese domestic tourists staying at one of Lijiang ancient city's B\&B facilities. The purpose was to determine whether behavioral intention of this group of people could be seen to be similar to that of tourists in other types of tourism activities. On the whole, it was found that the behaviour was similar and so the models that have been developed elsewhere may be extended to this part of the Chinese domestic tourism industry.

The survey was conducted on a convenience basis, since it was not known how many visitors in this sector there were altogether nor where they might be found, exactly. Consequently, the sample achieved might be vulnerable to the claims of being overly homogenous and suffering from non-response bias, despite attempts made to try to check for this. Quantitative research of this sort is always vulnerable to the challenges of space and time and whether results might have varied should one or both of these perimeters have been altered. To probe these issues further, it would be helpful to investigate heritage-style tourist accommodation in other locations across the country and in both smaller and larger research sites.

\section{Conflicts of Interest}

The authors declare no conflicts of interest regarding the publication of this paper.

\section{References}

Cheng, X. H. (2006). Study on Competitive Advantage of Forest Ecotourism Scenic Spots Based on Visitors Perceived Value. PhD Thesis, Hangzhou: Zhejiang University.

China Daily (2019). China Sees 783 mln Domestic Tourist Trips during National Day Holiday. https://www.travelchinaguide.com/tourism/2019statistics

China Industry Information Network (2020). Development of Outbound Tourism of Chinese Citizens in 2019 and Analysis of Outbound Tourism Market in 2020. http://www.chyxx.com/industry/202003/845172.html

China National Tourism Administration (2018). China Tourism Market and Comprehensive Data Report. http://www.gov.cn/xinwen/2018-01/14/content_5256502.htm

China State Administration of Cultural Relics (1985). Regulations on the Protection and Planning of Ancient Cities. Beijing: CSACR.

Ding, J. J., \& Li, C. J. (2017). Effect of Regional Differences on the Design of the B\&B 
Cultural Tourism-A Case Study in Erhai B\&B. Art Education, 6, 217-218.

Fu, Y. X., \& Liu, F. (2014). Research on Tourist's Perceived Value in International Youth Hostel-Based on Web Text Analysis. Commercial Research, 11, 157-161.

Jamal, S. A., Othman, N., \& Muhammad, N. M. N. (2011). Tourist Perceived Value in a Community-Based Homestay Visit: An Investigation into the Functional and Experiential Aspect of Value. Journal of Vacation Marketing, 17, 5-15. https://doi.org/10.1177/1356766710391130

Johnston, I. A. (2017). Is Chinese Nationalism Rising? Evidence from Beijing. International Security, 41, 7-43. https://doi.org/10.1162/ISEC_a_00265

Lee, C. K., Yoon, Y. S., \& Lee, S. K. (2007). Investigation the Relationships among Perceived Value, Satisfaction and Recommendations: The Case of Korean DMZ. Tourism Management, 28, 204-214. https://doi.org/10.1016/j.tourman.2005.12.017

Li, J. M. (2011). Study on the Relationships among Tourist Perceived Value, Satisfaction and Behavioral Intention in Recreation around Metropolis. $\mathrm{PhD}$ Thesis, Wuhan: China University of Geosciences.

Li, J. Y. (2018). Research on the Influencing Factors and Promotion Mechanism of Tea Tourism Consumption Satisfaction under the Perspective of Customer Perceived Value: Based on Tourism Consumption of Longjiang Tea in Hangzhuo. Master's Thesis, Hangzhou: Zhejiang Gongshang University.

Li, W. B., \& Zhang, H. M. (2010). An Empirical Study of Tourist Perceived Value Model of Ancient Villages: A Case Study on Zhangguying Village. Tourism Science, 24, 55-63.

Liang, M. Z., \& Jia, G. M. (2018). A Research on Tourists' Perceived Value and Evaluation of Rural Lodging: A Case of “Ten Thousand Hostel” in Zengcheng of Guangzhou. Journal of Guangzhou University (Social Science Edition), 17, 66-74.

Lijiang Tourism Bureau (2019). Lijiang Ancient City B\&B Information Announcement. http://www.ljta.gov.cn/html/infor/lvyouqiyepingdingliuchengjiminglu/2019/0409/1520 $\underline{6 . h t m l}$

Lijiang Tourism Bureau (2020). Lijiang Ancient City B\&B Catalogue. http://www.ljta.gov.cn/html/infor/lvyouqiyepingdingliuchengjiminglu/2015/1117/1341 $\underline{0 . h t m l}$

Liu, Y. (2011). Comparative Study on Chengdu Wuhouci Tourist's and Residents' Perceived Value. Master's Thesis, Chengdu: Southwest University of Finance and Economics.

Liu, Y., Kou, Y., Guan, Z. Z., \& Pu, B. (2019). The Impact Mechanism of Perceived Value on Hotel Brand Attachment: A Moderated Mediating Model. Tourism Tribune, 34, 29-39.

Lu, L., Liu, C. L., \& Liu, L. (2018). Ski Tourist Perceived Value and Satisfaction in Relation to Behavioral Intentions: A Case Study of Yunding Ski Resort in Chongli. Journal of Arid Land Resources and Environment, 32, 202-208.

Ma, L., \& Bao, J. G. (2012). A Study on Tourist Experience of Traditional Festivals from the Perspective of Perceived Value: An Example from Dai Ethnic Group's Water Splashing Festival at Xishuangbanna, China. Geographical Research, 31, 269-278.

Millar, S. (1989). Heritage Management for Heritage Tourism. Tourism Management, 10, 9-14. https://doi.org/10.1016/0261-5177(89)90030-7

Pan, J. (2008). Image Formation Process and Future Intentions through Tourist Functional Motivation and Perceived Value in Cultural Heritage Tourism. PhD Thesis, Stillwater, OK: Oklahoma State University.

Poria, Y., Butler, R., \& Airey, D. (2003). The Core of Heritage Tourism. Annals of Tourism Research, 30, 238-254. https://doi.org/10.1016/S0160-7383(02)00064-6 
Rasoolimanesh, S. M., Dahalan, N., \& Jaafar, M. (2016). Tourists' Perceived Value and Satisfaction in a Community-Based Homestay in the Lenggong Valley World Heritage Site. Journal of Hospitality \& Tourism Management, 26, 72-81.

https://doi.org/10.1016/j.jhtm.2016.01.005

Sampson, H. (2018). China's Domestic Tourism Boom Has Lessons for the Rest of the World.

https://skift.com/2018/08/18/chinas-domestic-tourism-boom-has-lessons-for-the-restof-the-world

Scaglione, A., \& Mendola, D. (2017). Measuring the Perceived Value of Rural Tourism: A Field Survey in the Western Sicilian Agritourism Sector. Quality \& Quantity, 51, 745-763. https://doi.org/10.1007/s11135-016-0437-8

Wang, C. H., Lu, L., Xia, Q. Y., \& Liu, X. (2011). An Empirical Study on the Model of Tourists Perception Value Measurement in Mega-Events: A Case Study of Domestic Tourists in 2010 Shanghai World Expo. Tourism Tribune, 26, 90-96.

Wang, L. (2019). Research on the Development of $B \& B$ in Banan District of Chongqing Based on Tourists' Perceived Value. Master's Thesis, Guiyang: Guizhou Normal University.

Wang, L. Y. (2018). Tourist Center of Linan Grand Canyon Village, Zhejiang Province. PhD Thesis, Hangzhou: Zhejiang Gongshang University.

Wang, Z. (2010). Factors That Influence the Growth of Chinese Domestic Tourism Arrivals (1985-2007): An Empirical Research Based on the VAR Model. Asia Pacific Journal of Tourism Research, 15, 449-459. https://doi.org/10.1080/10941665.2010.520947

Wen, Z. (1997). China's Domestic Tourism: Impetus, Development and Trends. Tourism Management, 18, 565-571. https://doi.org/10.1016/S0261-5177(97)00082-4

Wu, B., Zhu, H., \& Xu, X. (2000). Trends in China's Domestic Tourism Development at the Turn of the Century. International Journal of Contemporary Hospitality Management, 12, 296-299. https://doi.org/10.1108/09596110010339652

$\mathrm{Xu}, \mathrm{X} . \mathrm{L}$. (2015). An Empirical Study on the Impact of Customer Perceived Value on Customer Behavior Intention in Economical Hotels. PhD Thesis, Hohhot: Inner Mongolia University of Finance and Economics.

Yamane, T. (1973). Statistics: An Introductory Analysis (3rd ed.). New York: New York University Press.

Yang, L. (2013). Study on Tourists' Perceived Value of Japan's Traditional Festival. Master's Thesis, Changsha: Hunan Normal University.

Yang, Y., Liu, Z. H., \& Qi, Q. (2014). Domestic Tourism Demand of Urban and Rural Residents in China: Does Relative Income Matter? Tourism Management, 40, 193-202. https://doi.org/10.1016/j.tourman.2013.05.005

Yunnan Cultural Toursim Bureau (2006). Regulations on the Protection of Lijiang Ancient City of Yunnan Province. http://www.whyn.gov.cn/list/view/3/780

Zhang, T., \& Jia, S. H. (2008). A Study on the Dimensions and Measurement of Consumers' Perceived Values during Festivals. Tourism Tribune, 5, 4-78.

Zhao, L., Wu, W. Z., Li, J., \& Wu, Y. (2018). The Formation Mechanism of Tourist Loyalty in Ecotourism Scenic Spots from the Perspective of Tourist Perceived Value: Evidence from Xixi National Wetland Park. Acta Ecologica Sinica, 38, 7135-7147. https://doi.org/10.5846/stxb201707291366

Zheng, Y. B. (2014). Study on the Impacts of Customers' Travel Motivation and Perceived Value on Their Behavior Intention of Eco-Boutique Hotels. PhD Thesis, Hangzhou: Zhejiang University. 